University of Nebraska - Lincoln

DigitalCommons@University of Nebraska - Lincoln

$5-15-2003$

\title{
Bcl-2 Family Members Inhibit Oxidative Stress-Induced Programmed Cell Death in Saccharomyces cerevisiae
}

\author{
Shao-Rong Chen \\ University of Nebraska-Lincoln \\ David Dunigan \\ University of Nebraska-Lincoln, ddunigan2@unl.edu \\ Martin Dickman \\ University of Nebraska-Lincoln
}

Follow this and additional works at: https://digitalcommons.unl.edu/plantpathpapers

Part of the Plant Pathology Commons

Chen, Shao-Rong; Dunigan, David; and Dickman, Martin, "Bcl-2 Family Members Inhibit Oxidative StressInduced Programmed Cell Death in Saccharomyces cerevisiae" (2003). Papers in Plant Pathology. 127. https://digitalcommons.unl.edu/plantpathpapers/127

This Article is brought to you for free and open access by the Plant Pathology Department at DigitalCommons@University of Nebraska - Lincoln. It has been accepted for inclusion in Papers in Plant Pathology by an authorized administrator of DigitalCommons@University of Nebraska - Lincoln. 
Published in Free Radical Biology \& Medicine 34:10 (May 15, 2003), pp. 1315-1325; doi 10.1016/S0891-5849(03)00146-1

Copyright $\odot 2003$ Elsevier Inc. Used by permission. http://www.sciencedirect.com/science/journal/08915849

Submitted November 19, 2002; revised January 29, 2003; accepted February 21, 2003.

\title{
Bcl-2 Family Members Inhibit Oxidative Stress-Induced Programmed Cell Death in Saccharomyces cerevisiae
}

\author{
Shao-Rong Chen, David D. Dunigan, and Martin B. Dickman \\ Department of Plant Pathology, University of Nebraska-Lincoln, Lincoln, NE, USA \\ Correspondence - Dr. Martin B. Dickman, 406 Plant Sciences Hall, University of Nebraska-Lincoln, \\ Lincoln, NE 68583-0722, USA; tel (402) 472-2849; fax (402) 472-2853; email mdickman@unlnotes.unl.edu
}

\begin{abstract}
Selected antiapoptotic genes were expressed in baker's yeast (Saccharomyces cerevisiae) to evaluate cytoprotective effects during oxidative stress. When exposed to treatments resulting in the generation of reactive oxygen species (ROS), including $\mathrm{H}_{2} \mathrm{O}_{2}$, menadione, or heat shock, wild-type yeast died and exhibited apoptotic-like characteristics, consistent with previous studies. Yeast strains were generated expressing nematode $c e d-9$, human $b c l-2$, or chicken $b c l$ - $x l$ genes. These transformants tolerated a range of oxidative stresses, did not display features associated with apoptosis, and remained viable under conditions that were lethal to wildtype yeast. Yeast strains expressing a mutant antiapoptotic gene ( $b c l-2 \Delta \alpha 5-6)$, known to be nonfunctional in mammalian cells, were unable to tolerate any of the ROS-generating insults. These data are the first report showing CED-9 has cytoprotective effects against oxidative stress, and add CED-9 to the list of Bcl-2 protein family members that modulate ROS-mediated programmed cell death. In addition, these data indicate that Bcl-2 family members protect wild-type yeast from physiological stresses. Taken together, these data support the concept of the broad evolutionary conservation and functional similarity of the apoptotic processes in eukaryotic organisms.
\end{abstract}

Keywords: apoptosis, ROS, TUNEL, CED-9, heat shock, yeast, free radicals

\section{Introduction}

Oxidative stress has been implicated in numerous biological processes and diseases, including cancer, tumor promotion, arthritis, heart disease, aging, and programmed cell death in both plants and animals [1-4]. Thus, aerobic organisms need to mitigate the deleterious reactive oxygen species (ROS) that are generated during the normal course of aerobic metabolism to avoid oxidative damage. We are interested in oxidative stress and apoptosis, and the identification of genes that modulate these processes. Reactive oxygen species, including the superoxide anion $\left(\mathrm{O}_{2}{ }^{-}\right)$, hydrogen peroxide $\left(\mathrm{H}_{2} \mathrm{O}_{2}\right)$, and the hydroxyl radical $\left(\mathrm{OH}^{*}\right)$, are noted for their high reactivity and resultant damage to proteins, lipid membranes, and DNA [5]. When animal cells are exposed to these types of reactive oxygen species, cell death results with apoptotic morphology or necrotic characteristics, depending on the extent of the damage and duration of the stimulus. For example, oxidative stress induction can be chemically induced by menadione, an intracellu- lar generator of $\mathrm{O}_{2}{ }^{-}$, and often such treatment results in a dose-dependent apoptotic cell death [6].

When considering experimental systems for evaluating ROS-mediated toxicities, the yeast Saccharomyces cerevisiae is an excellent organism to study the regulation of heterologous gene expression in response to oxidative stress $[7,8]$. S. cerevisiae is sensitive both to $\mathrm{H}_{2} \mathrm{O}_{2}$ and to superoxide-generating agents [9-11]. Yeast deletion mutants of antioxidant genes such as catalase, superoxide dismutase, and cytochrome $c$ peroxidase result in strains hypersensitive to lethal effects of oxidative stresses relative to isogenic wild-type cells $[1,5,12]$. Growth under anaerobic condition does not exhibit such sensitivity to these mutants. Ectopic expression of the yeast $\mathrm{Cu}, \mathrm{Zn}-$ superoxide dismutase gene restores wild-type tolerance [13].

Yeasts have recently been used to study apoptosis, and a number of reports have provided evidence that $S$. cerevisiae (and fission yeast Schizosaccharomyces pombe) display several of the hallmark features associated with apoptosis, including chromatin condensation, 
DNA fragmentation, and external membrane exposure of phosphatidylserine $[7,14]$. Upon examination of the completed genomic sequence of $S$. cerevisiae, yeast have no apparent homologues of major apoptotic regulators (e.g., Bax/Bcl-2 family, caspases, Apaf-1/CED-4, etc.) described in metazoan organisms. Therefore, yeasts may be considered a genetically null background system to study interactions between heterologously expressed components of apoptotic pathways [15]. Expression of various apoptotic inducers, including Bax, caspases, p53, or CED-4/Apaf-1 results in death of $S$. cerevisiae [16-21]. Co-expression of Bax with Bcl-2 or Bcl-xL inhibits yeast cell death, as observed in animal cells $[16,17,22,23]$. In particular, the lethal phenotype of Bax-expressing yeast has been exploited for structure/ function studies, as well as gene-discovery efforts by screening for animal genes that suppress Bax-induced lethality [24,25].

Following treatment with $\mathrm{H}_{2} \mathrm{O}_{2}$ or depletion of glutathione, yeast exhibits apoptotic-like features prior to death [7]. Yeast cells can also be induced to die in an apoptotic-like manner by expression of Bax or treatment with cycloheximide, implying that yeast cell death is an active process, as it is in a number of cases in mammalian cells. In addition, aging in yeast also appears to be associated with apoptosis [26], and Bcl-2 can extend the life span of wild-type yeast and delay death in yeast mutants lacking superoxide dismutase [12]. A common theme through many of these studies is the accumulation of ROS. In this report we examine the phenotypical consequences of CED-9, Bcl-2, and Bcl-xL expression in yeast when various oxidative stresses $\left(\mathrm{H}_{2} \mathrm{O}_{2}\right.$, menadione, heat) were imposed under conditions that resulted in lethality to wild-type strains. In particular, we were interested in determining whether or not CED-9, a member of the Bcl-2 antiapoptotic family, inhibits necrotic and/or apoptotic-like cell death induced by different forms of oxidative stress, because Bcl-2 and Bcl-xL have been shown to be effective in mammalian cells in suppressing the toxic effects of ROS.

\section{Materials and Methods}

\section{Yeast strains, media, and transformations}

The S. cerevisiae strain EGY48 (MATa, ura3, his3, trp1, lexA $\mathrm{A}_{0,}$ [x6]-LEU2) was obtained from Clonetech (Palo Alto, CA, USA), and the growth, transformation, and expression of genes was performed essentially as described [27]. The EGY48 cells were grown in YPD medium containing $1 \%$ yeast extract, $2 \%$ Difco peptone, and $2 \%$ glucose. Plasmid DNA transformations were done by the $\mathrm{LiCl}$ method [28]; cells were grown in synthetic dropout (SD) medium with $2 \%$ glucose lacking histidine (SD/glu/ - his) as necessary to select for the presence of plasmids.

\section{Plasmid constructs}

The cDNAs encoding human $b c l-2$ (obtained from S.

Korsmeyer, Dana-Farber Cancer Institute, Boston [29]), chicken bcl-xl (obtained from C. Thompson, University of Chicago [30]) and C. elegans ced-9 (obtained from R. Horvitz, Massachusetts Institute of Technology, Cambridge [31]) were initially cloned between the Eco RI and Xho I restriction endonuclease cut sites in the yeast expression plasmid, pEG202 [32], which carries the S. cerevisiae HIS3 gene as a selectable marker. The following primers were used for Bcl-2: 5'-GGTGAATTCATGGCGCACGCTGGGAGAACA-3' (forward) and 5'-CCTCTCGAGTCACTTGTGGCCCAGATAGGC-3' (reverse); for Bcl-xL: 5'GGTGAATTCATGTCTCAGAGCAACCGGGAG-3' (forward) and 5'-CCTCTCGAGTCATTTCCGACTGAAGAGTGA-3' (reverse); for CED-9: 5'-GGTGAATTCATGACACGCTGCACGGCGGAC-3' (forward) and5'-CCTCTCGAGTTACTTCAAGCTGAACATCAT-3' (reverse). pEG202/Bcl-2 $\Delta \alpha 5-6$, a deletion mutant not effective in apoptosis mitigation [33], was provided by J. C. Reed (Bumham Institute, CA) and transformed into the EGY48 cells.

\section{Stress treatments and viability assays}

EGY48 cells harboring the constructs pEG202, pEG202-CED-9, pEG202-Bcl-2, pEG202-Bcl-xL, and pEG202-Bcl-2 $\Delta \alpha 5-6$ were grown overnight in SD media containing $2 \%$ galactose, $1 \%$ raffinose $(\mathrm{SD} /$ galraff/-his) as the carbon source. Early log phase yeast cultures $\left(\mathrm{A}_{600}=0.5\right)$ were diluted to a density of $\mathrm{A}_{600}$ $=0.05$ with $\mathrm{SD} /$ gal-raff $/$ - his and treated in one of the following ways. For chemical stress, $\mathrm{H}_{2} \mathrm{O}_{2}$, menadione, and verapamil were added at different concentrations and incubated at $30^{\circ} \mathrm{C}$ with vigorous shaking for $6 \mathrm{~h}$. For heat stress, yeast cells were incubated at $37^{\circ} \mathrm{C}$ for $30 \mathrm{~min}$ with vigorous shaking, transferred to a water bath at $50^{\circ} \mathrm{C}$ for 5 to $30 \mathrm{~min}$, then incubated at $30^{\circ} \mathrm{C}$ with vigorous shaking for $6 \mathrm{~h}$. Following these treatments, viability was determined by one or more of the following methods: staining with Evans blue [34] or plate counting of colony forming units (CFUs). For Evans blue staining, aliquots of cells were removed at regular intervals up to $6 \mathrm{~h}$ and a portion of the sample was incubated with $0.05 \%$ Evans blue for $15 \mathrm{~min}$ at room temperature, and washed with phosphate-buffered saline (PBS). Both the stained and unstained cells were observed microscopically (Zeiss Axioskop, Thornwood, NY, USA). For plate counting, $20 \mu \mathrm{l}$ of cells were sampled at regular intervals up to $6 \mathrm{~h}$ and spread onto YPD medium with $2 \%$ agar, then incubated at $30^{\circ} \mathrm{C}$ for $48 \mathrm{~h}$. The numbers of CFUs were compared between treated and untreated cells. All experiments were repeated at least in triplicate. 
Terminal deoxynucleotidyl transferase-mediated dUTP nick end labeling (TUNEL)

Treated and untreated cells were fixed with 3.7\% fresh formaldehyde, digested with lyticase (5 units $/ \mu 1$ for $30 \mathrm{~min}$ at $37^{\circ} \mathrm{C}$ ), then electrostatically bound to a glass slide (Fisherbrand Superfrost Plus, Pittsburgh, PA, USA). The slides were rinsed with PBS, incubated in permeabilization solution $(0.1 \%$ Triton X-100, $0.1 \%$ sodium citrate) for $2 \mathrm{~min}$ on ice, rinsed twice with PBS, incubated with $10 \mu \mathrm{l}$ terminal deoxynucleotidyl transferase-mediated dUTP nick end labeling (TUNEL) reaction mixture $(200 \mathrm{U} / \mathrm{ml}$ terminal deoxynuleotidyl transferase, $1 \mathrm{mM}$ FITC-labeled dUTP, $25 \mathrm{mM}$ Tris/HCl, 200 $\mathrm{mM}$ sodium cacodylate, $5 \mathrm{mM}$ cobalt chloride; "In Situ Cell Death Detection Kit, Fluorscein," Roche Diagnostics Co., Indianapolis, IN, USA) for $60 \mathrm{~min}$ at $37^{\circ} \mathrm{C}$, and rinsed three times with PBS. The slides were then incubated with $1 \mu \mathrm{g} / \mathrm{ml}$ diaminophenylindole (DAPI) in PBS for $10 \mathrm{~min}$ at room temperature, rinsed twice with PBS, and analyzed by epifluorescence microscopy (Zeiss Axioskop) using a Ph3 Plan-Apopchromat 100×/1.4 oil emersion lens, and images were captured with a color imaging system with basic resolution of $1300 \times 1030$ pixels and digital imaging software (AxioCam HR, Thornwood, NY, USA).

\section{Annexin V staining}

To examine phosphatidylserine externalization, FITCcoupled annexin V (Annexin V FITC Apoptosis Detection Kit; Oncogene Research Products, Boston, MA, USA) was reacted with yeast cells prepared essentially as described by Madeo et al. [24]. $\mathrm{H}_{2} \mathrm{O}_{2}$ treatments were identical to those described above.

\section{Flow cytometric studies}

Cultures of untreated, logarithmically growing cells in $\mathrm{SD} /$ gal-raff/ - his at a density of $\mathrm{A}_{600}=0.05$ were treated briefly with sonication to disrupt aggregates, then processed for detection of ROS production. Intracellular ROS production was measured by staining with the dye $2^{\prime} 7^{\prime}$-dichlorohydrofluoroscein diacetate (DCFH-DA, Molecular Probes, Eugene, OR, USA). Data were collected by measuring aliquots of cells removed at selected intervals up to $6 \mathrm{~h}$ and a portion of the sample was incubated with $50 \mu \mathrm{M}$ final concentration of DCFH-DA for $20 \mathrm{~min}$ at room temperature, and both stained and unstained cells were read with a FACScan fluorescence activated cell scanner using the data acquisition program CELLQuest (Becton Dickinson, CA, USA). Fifty thousand cells were read per sample.

\section{Results}

\section{Transgene expression in yeast}

Yeast transformed with pEG202-empty vector or strains expressing animal genes were morphologically indistinguishable and the growth rates, based on doubling times determined spectrophotometrically, were also equivalent $(4.7 \pm 0.3 \mathrm{~h})$. To evaluate transgene expression, three colonies of each yeast genotype were selected randomly and analyzed for levels of CED-9, Bcl-2, Bcl-2 $\Delta \alpha 5-6$, and Bcl-xL proteins using Western immunoblot assays. The expression levels of three colonies of CED-9, Bcl-2, Bcl-2 $\Delta \alpha 5-6$, and Bcl-xL, were similar (data not shown). No signal was observed when pEG202 empty vector proteins were probed with any of the antiapoptotic antibodies. Thus, S. cerevisiae cells expressed the transferred genes at comparable levels and did not have any discernable physiological costs associated with such expression.

\section{Expression of CED-9, Bcl-2, and Bcl-xL confers resistance to} cell death induced by oxidative stress

To determine whether selected antiapoptotic proteins could protect cells from death associated with oxidative stress, CED-9, Bcl-2, and Bcl-xL were expressed in the yeast strain EGY48, as described. Cells were grown in SD/gal-raff/ - his medium and were exposed to increasing concentrations of $\mathrm{H}_{2} \mathrm{O}_{2}$ and menadione (Figure 1). Aliquots of cells were removed at $2 \mathrm{~h}$ intervals up to $6 \mathrm{~h}$ and viability was determined by staining with Evans blue, as well as plate counting.

Expression of the pEG202-CED-9, pEG202-Bcl-2, and pEG202-Bcl-xL significantly enhanced the viability of EGY48 cells exposed to $3 \mathrm{mM} \mathrm{H}_{2} \mathrm{O}_{2}$ (Figure 1A) and 3 $\mathrm{mM}$ menadione for $6 \mathrm{~h}$ (Figure $1 \mathrm{~B}$ ). Following treatment of $3 \mathrm{mM} \mathrm{H}_{2} \mathrm{O}_{2}, 63 \%$ of the pEG202-CED-9, $66 \%$ of the pEG202-Bcl-xL, and $61 \%$ of the pEG202-Bcl-2 cells remained viable, as compared to $24 \%$ of the pEG202 control cells. Importantly, when yeast harboring the Bcl-2 mutant (Bcl-2 $\Delta \alpha 5-6)$, which is nonfunctional in mammalian cells [33], viability was similar to the control yeast strain $(21 \%)$ following menadione treatment; as compared to greater than $60 \%$ viability for strains expressing antiapoptotic genes. Expression of the pEG202CED-9, pEG202-Bcl-2, and pEG202-Bcl-xL genes also resulted in comparable, but reduced levels of resistance to $5 \mathrm{mM} \mathrm{H}_{2} \mathrm{O}_{2}$, and $5 \mathrm{mM}$ menadione (Figure 1). Again, expression of the antiapoptotic mutant gene did not confer increased tolerance to these stresses, resulting in levels of viability similar to controls $\left(15 \%\right.$ for $\mathrm{H}_{2} \mathrm{O}_{2}, 14 \%$ for menadione). These differences are not attributable to differences in protein levels, as Western immunoblotting analyses showed similar amounts of transgene expression. When higher levels $\left(10 \mathrm{mM}\right.$ of $\mathrm{H}_{2} \mathrm{O}_{2}$ or mena- 

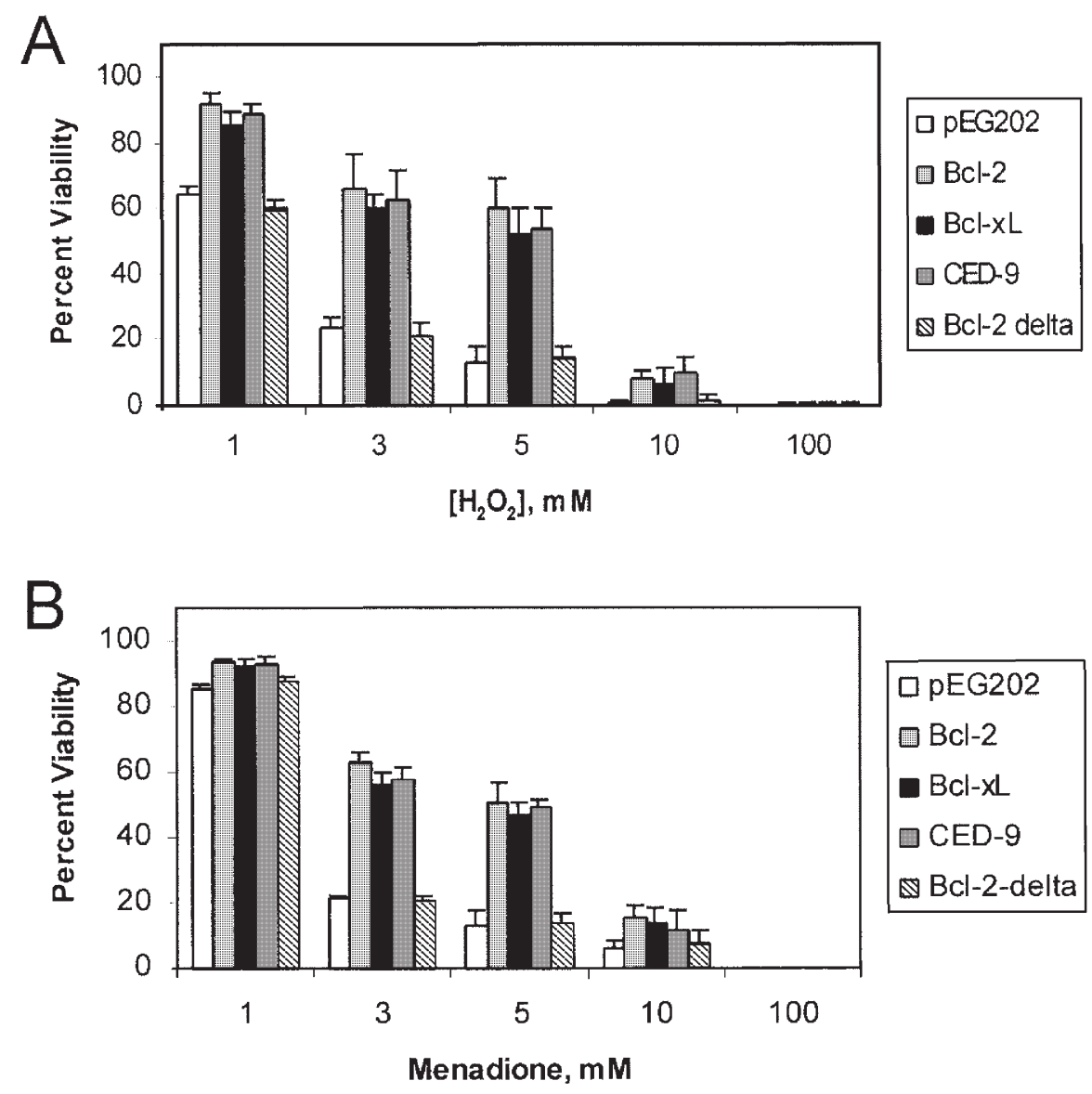

Figure 1. Viability analysis of yeast challenged with ROS-mediating hydrogen peroxide or menadione. Treated cells were processed as described in Materials and Methods. Percent viability was determined by counting total and Evan's blue staining cells as viewed in a microscopic field of at least 100 cells, then dividing the number of Evan's blue cells by the total. The values represent the mean of three experiments with (A) hydrogen peroxide- or (B) menadione-treated cells; error bars represent the standard deviation. Viability with no treatment was set at 100\%. Bcl-2 delta refers to the pEG202 Bcl-2 $\Delta \alpha 5-6$.

dione) were used, viability in all yeast cells, including transformed strains, was considerably reduced and decreased nearly to zero when concentrations were increased to $100 \mathrm{mM}$.

To further establish that transformed yeast strains tolerated these oxidative stresses via specific apoptotic-like responses, cells were treated with verapamil, a calcium channel blocker not associated with PCD, but known to be lethal to eukaryotic cells [35]. Control cells and all transformants had similar, low levels of viability following $2 \mathrm{~h}$ treatment with $5 \mathrm{mM}$ verapamil. Antiapoptotic expressing and control cells showed identical phenotypes when treated with different concentrations of verapamil (Table 1). The viability of yeast cells was unaffected at $1 \mathrm{mM}$ verapamil, and decreased slightly when exposed to $3 \mathrm{mM}$ verapamil for $2 \mathrm{~h}$. Five millimolar verapamil treatment decreased viability to about $50 \%$, and at $10 \mathrm{mM}$ viability was reduced to nearly zero for all cells. Thus, all cells were equally susceptible to verapamil, whereas, the transgenic yeast were differentially susceptible to the ROS mediators.

\section{CED-9, Bcl-2, and Bcl-xL inhibit cell death induced by heat stress}

Because oxidative stress and antioxidant enzymes play a major role in heat-induced cell death in yeast [36], we were interested in evaluating transgenic yeast viability following heat stress. Yeast cells expressing CED-9,

Table 1. Percent Viability of Yeast Cells Treated with Verapamil

\begin{tabular}{lcccl}
\hline Yeast Strain & $1 \mathrm{mM}$ & $3 \mathrm{mM}$ & $5 \mathrm{mM}$ & $10 \mathrm{mM}$ \\
\hline pEG202-empty vector & $96 \pm 2$ & $87 \pm 1$ & $50 \pm 3$ & $5 \pm 1$ \\
CED-9 & $96 \pm 2$ & $86 \pm 2$ & $50 \pm 2$ & $5 \pm 2$ \\
Bcl-2 & $96 \pm 2$ & $88 \pm 2$ & $50 \pm 2$ & $5 \pm 2$ \\
Bcl-xL & $95 \pm 2$ & $87 \pm 2$ & $50 \pm 3$ & $5 \pm 2$ \\
Bcl-2 $\Delta \alpha 5-6$ & $95 \pm 1$ & $86 \pm 2$ & $49 \pm 2$ & $5 \pm 1$ \\
\hline
\end{tabular}

Yeast cells were treated with verapamil for $2 \mathrm{~h}$ and processed for viability analysis, as described in Materials and Methods. Viability was determined using the fraction of Evan's blue staining cells relative to the total number of cells. The values represent the means and standard deviations of three independent experiments. 

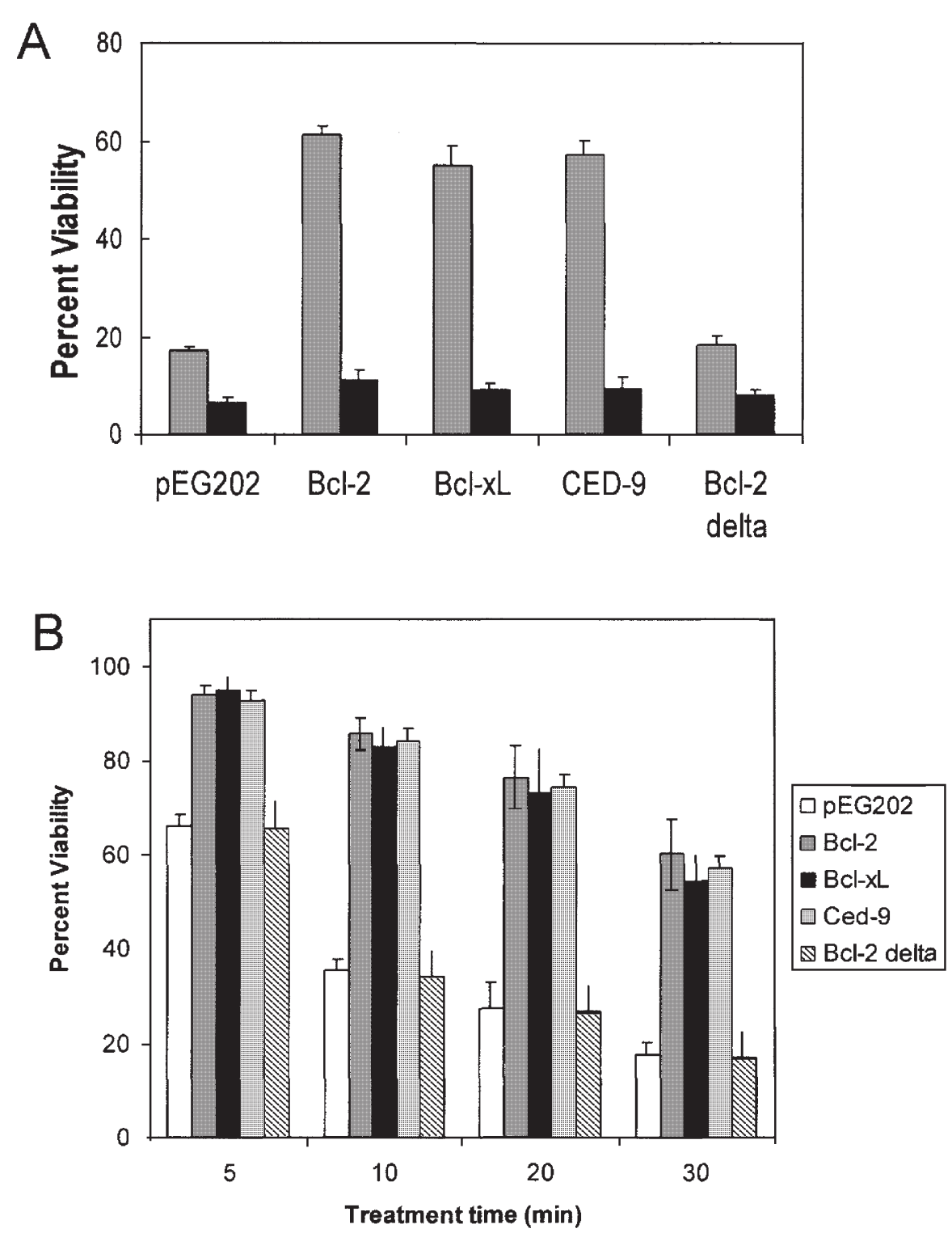

Figure 2. Viability analysis of yeast challenged with heat stress. Heat-treated cells were processed as described in Materials and Methods. Panel A represents cells with no pretreatment (black bars) or pretreated at $37^{\circ} \mathrm{C}$ for 30 min, then stressed with $50^{\circ} \mathrm{C}$ for $30 \mathrm{~min}$ (gray bars). Panel B represents cells that, after a pretreatment, were heat stressed for varying periods, then counted after $6 \mathrm{~h}$ of treatment. Percent viability was determined by counting total and Evan's blue staining cells as viewed in a microscopic field of at least 300 cells, then dividing the number of Evan's blue cells by the total. The values represent the mean of 5 samples and the error bars represent the standard deviations. Viability with no heat stress was set at $100 \%$. Bcl-2 delta refers to the pEG202 Bcl-2 $\Delta \alpha 5-6$.

$\mathrm{Bcl}-2$, or $\mathrm{Bcl}-\mathrm{xL}$ were exposed to lethal $\left(50^{\circ} \mathrm{C}\right)$ heat stress (5 to $30 \mathrm{~min}$ ) following a pretreatment at $37^{\circ} \mathrm{C}$ for 30 min. Without pretreatment, direct incubation of either antiapoptotic expressing or control cells at $50^{\circ} \mathrm{C}$ was lethal. As with ROS treatments, viability of transformed yeast strains was between 54 and 60\%; whereas control cells were $18 \%$ and cells expressing Bcl-2 $\Delta \alpha 5-6$ were $16 \%$, following $30 \mathrm{~min}$ treatments at $50^{\circ} \mathrm{C}$ (Figure $2 \mathrm{~A}$ ). As expected, viability was temperature and time dependent. However, additional heat treatment of cells resulted in sustained viability of yeast expressing CED-
9, Bcl-2, or Bcl-xL, whereas the viability of control cells dramatically decreased (Figure 2B).

Effects of CED-9, Bcl-2, and Bcl-xL on the generation of ROS during heat stress

To assess the formation of reactive oxygen metabolites during cell death, intracellular ROS levels were measured using a cell-permeant oxidant-sensitive fluorescent probe, DCFH-DA. Reactive oxygen species (such as $\mathrm{H}_{2} \mathrm{O}_{2}, \mathrm{HO}^{\circ}$, $\mathrm{HOO}^{\circ} \mathrm{ONOO}^{\circ}$, or $\mathrm{O}_{2}{ }^{-}$) in cells cause oxidation of DCFH-DA yielding the green fluorescent 


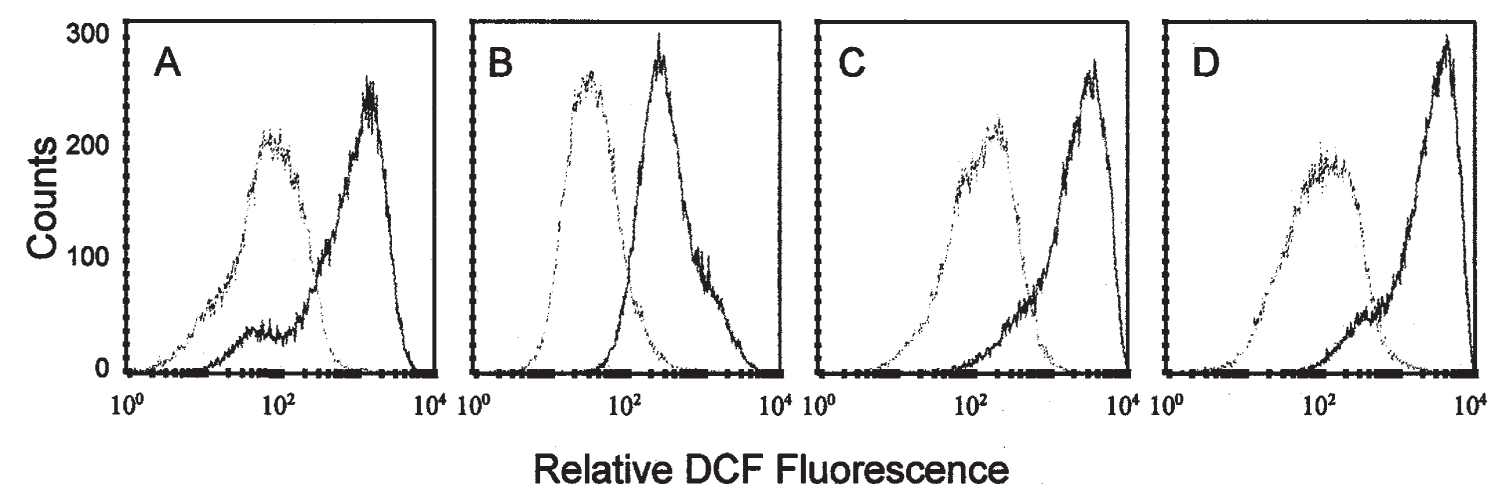

Figure 3. Fluorescence activated flow cytometric determination of intracellular ROS measure by activation of $2^{\prime} 7^{\prime}$-dichlorohydrofluoroscein diacetate $\left(\mathrm{H}_{2} \mathrm{DCFH}-\mathrm{DA}\right)$. Yeast cells were transformed EGY48 to express Bcl-2 (B), Bcl-xL (C), CED-9 (D), with pEG202 as an empty vector control (A), were grown for $24 \mathrm{~h}$ to approximately $\mathrm{A}_{600}=0.5$ in SD/gal-raff/ - his medium. The cells were diluted to $\mathrm{A}_{600}=0.1$. The culture was split where half was maintained at $30^{\circ} \mathrm{C}$ (gray line, left shifted), the other half was pretreated at $37^{\circ} \mathrm{C}$ for $30 \mathrm{~min}$, then heat stressed at $50^{\circ} \mathrm{C}$ for $30 \mathrm{~min}$ (black line, right shifted). Both sets of cells were subsequently incubated at $30^{\circ} \mathrm{C}$ for $6 \mathrm{~h}$, then treated with DCFH-DA at $50 \mu \mathrm{M}$ final concentration for $20 \mathrm{~min}$ at $25^{\circ} \mathrm{C}$. Relative fluorescence units were set by gating to eliminate autofluorescence from non-DCFH-DA-treated cells, then 50,000 cells of each sample were analyzed with a Becton-Dickinson FACS Scan, argon laser with excitation at $488 \mathrm{~nm}$. The histograms shown are representative of five independent experiments.

product $2^{\prime}, 7^{\prime}$-dichlorofluorescein (DCF) [37]. The levels of ROS in heat-stressed cells, relative to the nonstressed controls, had higher DCF fluorescence values for all cell types tested (Fig. 3). The basal level of DCF activation in nonstressed cells was slightly variable between experiments, but the heat-treated cells consistently resulted in enhanced ROS levels, as measured with DCF.

CED-9, Bcl-2, and Bcl-xL inhibit apoptotic-like death of yeast induced by oxidative stress

Oxidative damage can result in cell death by either apoptosis or necrosis, depending on the degree of amage. To determine whether CED-9, Bcl-2, or Bcl-xL inhibit either necrotic or apoptotic cell death in yeast cells, stress-induced cells were examined for nuclear markers of apoptosis. DNA fragmentation was assayed using the TUNEL reaction [38]; chromatin condensation was visualized by fluorescence microscopy following DAPI staining (Figure 4 and Table 2).

Relatively low concentrations of $\mathrm{H}_{2} \mathrm{O}_{2}$ or menadione resulted in a TUNEL-positive phenotype, which was not evident at higher concentrations even though death occurred in both instances (Table 2). Eight hour incubations with either $3 \mathrm{mM} \mathrm{H707}$ or $3 \mathrm{mM}$ menadione produced a strong TUNEL-positive reaction in approximately $70 \%$ of the pEG202 $\Delta \alpha 5$-6-expressing cells, indicating DNA fragmentation, but $20-30 \%$ of the CED9-, Bcl-2-, or Bcl-xL-expressing cells were TUNEL positive. Evans blue staining of these cells as an indicator of membrane damage and death was consistent with these observations. Cell death induced by oxidative stress exhibited chromatin condensation in pEG202 and yeast expressing Bcl-2 $\Delta \alpha 5-6$. Both strains also showed the ap- pearance of large bodies that reacted positively to the TUNEL label and the DAPI stain (Fig. 4A). The presence of distinct, well-separated apopototic bodies, indicative of relatively late stages of apoptosis, were also observed and resolved from the background staining with contrast enhancement of the digital image (Figure 4B). Thus, there was a good correlation between the inhibition of yeast death and with the expression of mammalian antiapoptotic genes. Analysis of DNA from treated cells by agarose gel electrophoresis did not show DNA laddering (data not shown), which is often observed in apoptotic cell death of higher eukaryotes. DNA laddering, however, is not requisite for programmed cell death [39], and has not been reported in yeast programmed cell death.

Table 2. Percent TUNEL Positive Nuclei of Treated Yeast

\begin{tabular}{llllll}
\hline & \multicolumn{2}{c}{$\begin{array}{c}\text { Hydrogen } \\
\text { peroxide }\end{array}$} & & \multicolumn{2}{c}{ Menadione } \\
\cline { 2 - 3 } \cline { 6 - 7 } Yeast strain & $3 \mathrm{mM}$ & $5 \mathrm{mM}$ & & $3 \mathrm{mM}$ & $5 \mathrm{mM}$ \\
\hline CED-9 & $31 \pm 4$ & $6 \pm 2$ & & $30 \pm 4$ & $8 \pm 5$ \\
Bcl.2 & $21 \pm 4$ & $6 \pm 1$ & & $26 \pm 4$ & $7 \pm 3$ \\
Bcl-2 $\Delta \alpha 5-6$ & $67 \pm 6$ & $9 \pm 2$ & & $68 \pm 5$ & $12 \pm 5$ \\
Bcl-xL & $30 \pm 5$ & $7 \pm 3$ & & $27 \pm 4$ & $9 \pm 5$ \\
pEG202 empty vector & $70 \pm 3$ & $8 \pm 4$ & & $68 \pm 5$ & $9 \pm 5$ \\
\hline
\end{tabular}

Yeast cells were treated with either hydrogen peroxide or menadione at the indicated concentrations for $8 \mathrm{~h}$, then processed for evaluating DNA degradation. The number of cells resulting in TUNEL positive nuclei was determined by double staining of cells with $10 \mu \mathrm{M}$ of DAPI to estimate the total number of nuclei, and TUNEL staining following the manufacturer's recommendation (see Materials and Methods). Greater than 300 cells per treatment were counted per experiment. The values represent the mean of three experiments and the errors represent the standard deviation. 


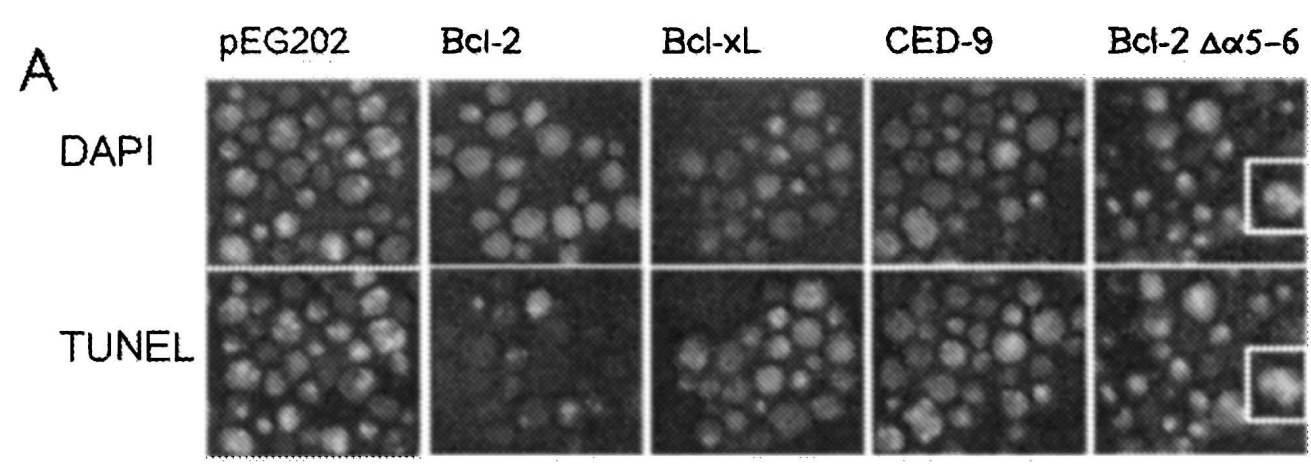

B
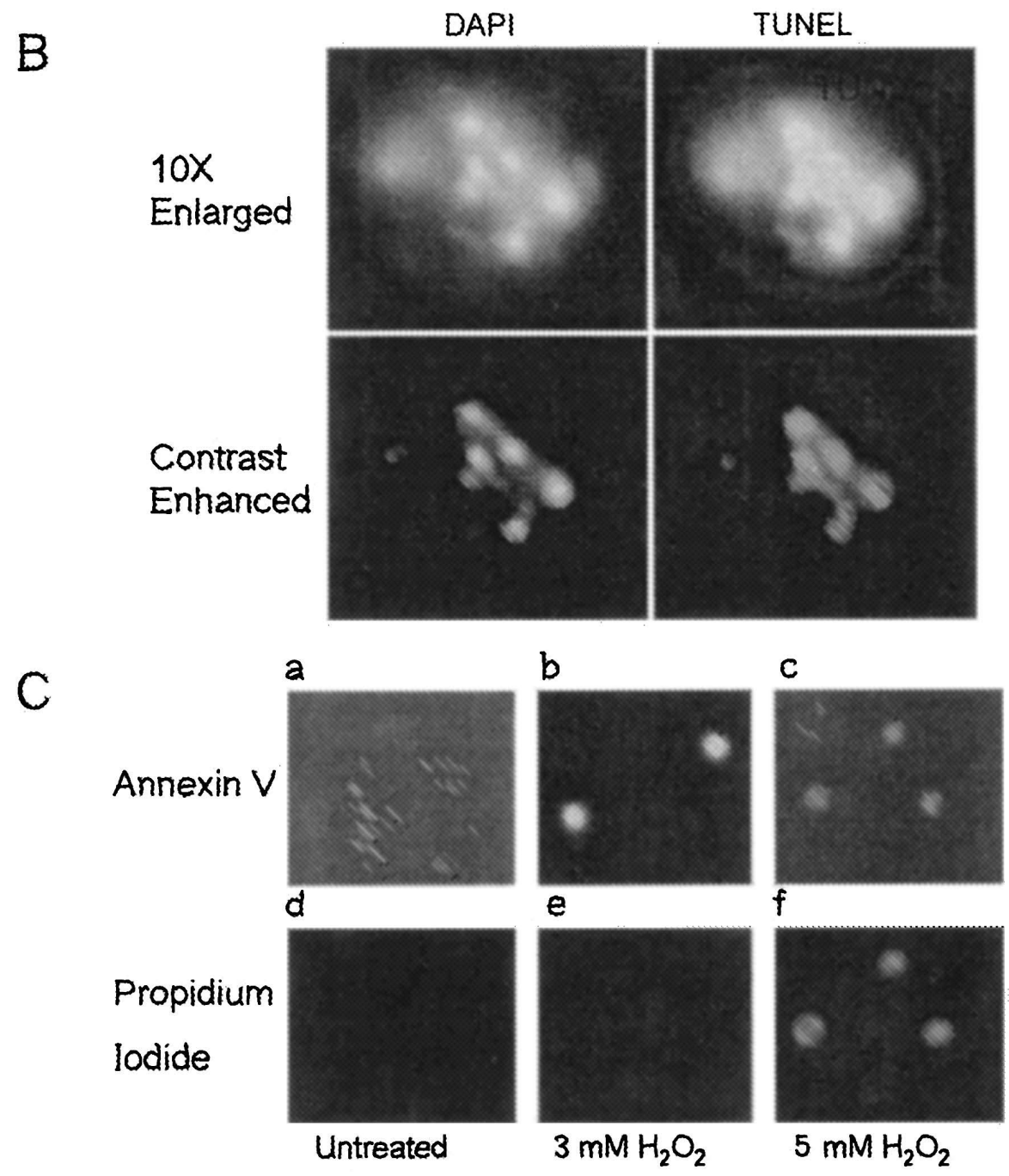

Figure 4. Microscopic analysis of markers for apoptosis in hydrogen peroxide treated yeast. Hydrogen peroxide treated cells were processed for microscopic analyses as described in Materials and Methods. The cells were treated with $3 \mathrm{mM} \mathrm{H}_{2} \mathrm{O}_{2}$ for $6 \mathrm{~h}$, fixed with formaldehyde and the cell walls were digested with lyticase, then reacted with the TUNEL reagents and counter-stained with DAPI (A). An example of the structural changes associated with dying cells is shown in (B), where one cell (white box highlighted in the Bcl-2 $\Delta \alpha 5-6$ sample) was enlarged 10-fold, then imaging enhancement was applied by adjusting the contrast levels to resolve the strongly staining DNA structures. Cell surface exposure of phosphatidylserine is shown in (C). Annexin V binding assay is shown in panels a-c; propidium iodide staining is shown in panels d-f.

To more precisely characterize the apoptotic phenotype, localization of phosphatidylserine (PS) was performed. Staining of cells with FITC-conjugated annexin
$\mathrm{V}$ reveals externalization from the inner to the outer membrane, a biochemical marker for apoptosis. In necrotic cells, annexin V can enter the dying cells and bind 
to PS exposed on the inner leaflet of the cell membrane. To distinguish apoptotic from necrotic death, yeast cells were simultaneously stained with propidium iodide (PI), a DNA stain that is not cell permeable. The apoptotic cells label annexin $\mathrm{V}$ positive, PI negative, and necrotic cell label positive for both stains. As shown in Figure $4 \mathrm{C}, 3 \mathrm{mM} \mathrm{H}_{2} \mathrm{O}_{2}$ induced apoptosis; $5 \mathrm{mM} \mathrm{H}_{2} \mathrm{O}_{2}$ induced necrosis.

Taken together, it appears the control yeast cells were dying in an apoptotic-like manner with $3 \mathrm{mM}$ of the reagents, consistent with previous reports [7]. Increasing the $\mathrm{H}_{2} \mathrm{O}_{2}$ or menadione concentrations to $5 \mathrm{mM}$ or greater did not increase the percentage of TUNEL reacting cells, in fact, the TUNEL positive cells decreased in number and staining intensity as the concentration of stressors increased (Table 2), although more cells were Evans blue positive, suggesting that these cells were likely dying by necrosis. Cells incubated in the absence of $\mathrm{H}_{2} \mathrm{O}_{2}$ and menadione were negative for the TUNEL reaction. Cells incubated with verapamil from 1 to 10 $\mathrm{mM}$, or treated with $50^{\circ} \mathrm{C}$ heat stress from 5 to $30 \mathrm{~min}$ (no pretreatment) also did not stain for TUNEL (data not shown), indicating that these stresses resulted in a necrotic-type death.

\section{Discussion}

The yeast $S$. cerevisiae has been shown to be a useful model for apoptosis research $[14,25]$. While not all of the defining features of metazoan PCD have been observed in yeast, it has become evident that PCD occurs, exhibiting at least some of these features. In this report, we describe the results of imposing various oxidative stressors to wild-type and yeast-expressing antiapoptotic genes. In wild-type yeast, a number of processes associated with apoptosis, including chromatin condensation and DNA fragmentation, occur prior to cell death, consistent with previous studies $[7,15,40]$. Importantly, we show that yeast strains expressing the selected antiapoptotic genes (C. elegans ced-9, human $b c l-2$, chicken $b c l-x l)$ do not exhibit apoptotic morphologies and do not die, under conditions where wild-type yeast result in an apoptotic-like death.

Oxidative damage can cause cell death in aerobically growing cells by either apoptosis or necrosis, depending on the extent of cellular damage. The response of yeast when treated with ROS-generating agents is consistent with this observation, as lower doses of $\mathrm{H}_{2} \mathrm{O}_{2}$ or menadione resulted in a clear apoptotic morphology (Figure 4) and subsequent death, neither of which occurred when either CED-9, Bcl-2, or Bcl-xL were expressed. Higher doses of ROS-generating reagents caused a necrotic-like death, as determined by vital stains and viability assays, where apoptotic-like fea- tures were not observed. Transformed yeast were not protected under these conditions, suggesting that the death balance was tipped from apoptosis to necrosis with higher levels of these noxious agents. Further, all strains were equally susceptible to verapamil, an inducer of necrosis, and there were no measurable features of PCD observed in the dying cells. The specificity of transgene protection was further demonstrated by expressing the mutant Bcl-2 $\Delta \alpha 5-6$, which exhibits a null phenotype with respect to cytoprotection in mammalian cells [33]. When Bcl-2 $\Delta \alpha 5-6$ was expressed in yeast, there was no protection against $\mathrm{H}_{2} \mathrm{O}_{2}$, menadione, or heat at levels that induced apoptosis in wildtype strains.

It is known that Bcl-2 prevents many forms of programmed cell death. Previous work by Longo et al. [12] has shown that yeast cells harboring Bcl-2 have enhanced survival ability. Under stationery phase death conditions, yeast cells expressing Bcl-2 live considerably longer than wild-type strains. Yeast strains defective in antioxidant protection by deletion of the superoxide dismutase gene exhibit growth and survival deficiencies, which are substantially improved by Bcl-2 expression. Bcl-2 also provides cytoprotection from $\mathrm{H}_{2} \mathrm{O}_{2}$ and menadione-induced oxidative death in animals [4 1-43]. We now can extend these observations to yeast. To directly assess the formation of reactive oxygen metabolites during cell death, intracellular ROS levels were measured using a cell-permeant oxidant-sensitive probe DCFHDA. Our observations in these studies are concordant with previous studies [41], where Bcl-2 did not block free radical generation but did prevent ROS-mediated PCD. However, to our knowledge, CED-9 has not been associated with ROS. Because human Bcl-2 can functionally substitute for CED-9 in C. elegans, our observations are consistent with the ability of Bcl-2 gene family members to functionally overlap. Whether CED-9 has a functional role in ameliorating oxidative stress in the worm is not known.

Oxidative stress also occurs during heat-induced cell death in yeast and mammals $[36,44,45]$. When exposed to heat stress conditions, the levels of ROS production also increased in both transgenic and control yeast but only resulted in death of wild-type yeast cells (Figure 1). Yeast heat-shock protein 104 (Hsp104) is specifically induced by heat stress and appears to be the major yeast Hsp involved in the acquisition of thermotolerance [46]. Hsp104 is strongly induced by $37^{\circ} \mathrm{C}$ heat shock [46], resulting in partial protection of yeast stains subsequently exposed to high temperatures $(30$ $\min , 50^{\circ} \mathrm{C}$ ). However, yeast-expressing antiapoptotic proteins were protected to a greater extent (higher frequencies) and tolerated longer heat exposures (Figure 3). This enhancement of protection was dependent upon the presence of Hsp104, as Hsp104 null mutants 
harboring antiapoptotic genes were not thermotolerant and responded similarly to the nontransformed deletion mutant (data not shown). Thus, it is reasonable to suggest that CED-9, Bcl-2, and Bcl-xL function in an antioxidant pathway to prevent cell death from lethal heat stress by positively cooperating (directly or indirectly) with Hsp104.

The counter-intuitive notion that apoptosis occurs in unicellular yeast has been discussed [47, and references therein]. A number of recent reports indicate that apoptotic-like phenotypes occur in S. cerevisiae [15], and, as with bacteria and fission yeast, suicide is reconciled as a population effect, where the cell sacrifices itself for the betterment and maintenance of the whole. Expression of animal proapoptotic genes (e.g., bax, bak, ced-4) results in yeast cell death that, morphologically, is consistent with apoptosis. In addition, $S$. cerevisiae harboring a cell cycle mutation (cdc48) also displays several characteristic morphological features of apoptosis [48]. Based on these, as well as our own studies, yeast appear to exhibit a number of markers of apoptosis, including condensation of chromatin, fragmentation of DNA, and exposure of phosphatidlyserine to the external region of the plasma membrane. Using DAPI and TUNEL reactions to stain yeast nuclei, we observed distinct chromatin condensation coincident with DNA fragmentation, especially in samples treated with hydrogen peroxide or menadione (Figure 4). With the enhanced capability of high density digital image capture and contrast enhancement, we resolved subnuclear DNA structures consistent with the early stages of formation of apoptotic bodies. Again, these data draw parallels to observations of PCD in animal cells where the defining characteristics include nuclear pyknosis and DNA fragmentation. These parallels are significantly furthered by the recent report that yeast cells harbor a cysteine protease distantly related to mammalian caspases, designated metacaspases [49]. The yeast metacaspase not only has structural, but also functional homology to mammalian caspases. When yeast are treated with $\mathrm{H}_{2} \mathrm{O}_{2}$ to undergo apoptosis, a caspase-like proteolytic activity is activated. When this gene is inactivated by disruption, apoptosis does not occur. Overexpression of the yeast metacaspase induces apoptosis. This enzyme is also involved in regulating the death process in aging yeast cultures.

In all of these studies, we could not observe DNA laddering, although such laddering is not essential for apoptosis to occur in mammalian cells. In addition, $S$. cerevisiae chromatin structure has been reported to have little or no linker DNA between nucleosomes, which would preclude ladder formation [49]. The ability of yeast to die in an apoptotic-like manner is consistent with the idea that programmed cell death was in place before the divergence of yeast and metazoans.
Expression of proapoptotic genes (e.g., bax, bak, ced4) can induce cell death in yeast that can be rescued by antiapoptotic gene expression $[16,17,20,23,33]$. Because foreign gene expression can nonspecifically induce cell death, it is not clear whether inhibition of cell death involves a specific apoptotic process or rather only nonspecific inhibition (e.g., Bax-Bcl-2 dimerization). Our results demonstrate a clear cytoprotective effect for CED-9, Bcl-2, and Bcl-xL in the absence of Bax or any other proapoptotic gene. Because we imposed conditions of physiological duress, these data suggest that a bona fide cell death program occurs in yeast. Moreover, the antideath activity associated with expression of the transgenes correlates to the absence of apoptotic features (DNA fragmentation), which we readily observe in wild-type cells prior to cell death.

These data also support the use of yeast as a high throughput heterologous system for screening and identifying functionally relevant genes of interest that regulate apoptosis [50]. This approach is particularly useful in situations where functional screens are not experimentally well developed (e.g., plants) [27,51-53]. For example, we recently reported that expression of animal antiapoptotic genes (e.g., Bcl-xL, CED-9, Op-IAP) in tobacco plants confers heritable resistance to several necrotrophic fungal and viral pathogens [54]. Because ROS generation is commonly associated with disease development and host resistance [55,56], yeast may prove to be an attractive system to identify candidate plant genes with the functional ability to modulate plant cell death generated by ROS.

\section{Acknowledgments}

We wish to thank Dr. R. Horvitz for ced-9 and CED-9 antibody, Dr. Stanley Korsmeyer for human bcl-2, Dr. C. Thompson for chicken bcl-xl,and Dr. J. Reed for Bcl-2 antiserum. This research was supported by National Science Foundation Grant IBN-0133078.

\section{References}

[1] Cerutti, P. A. Prooxidant states and tumor promotion. Science 227: 375-381; 1985.

[2] Pierce, G. B., Parchment, R. E., Lewellyn, A. L. Hydrogen peroxide as a mediator of programmed cell death in the blastocyst. Differentiation 46: 181-186; 1991.

[3] Halliwell, B. Reactive oxygen species and the central nervous system. J. Neurochem. 59: 1609-1623; 1992.

[4] Shigenaga, M. K., Hagen, T. M., Ames, B. N. Oxidative damage and mitochondria1 decay in aging. Proc. Natl. Acad. Sci. USA 91: 10771-10778; 1994.

[5] Halliwell, B., Gutteridge, J. M. Oxygen toxicity, oxygen radicals, transition metals and disease. Biochem. J. 219: 1-14; 1984. 
[6] Storz, G., Tartaglia, L. A., Farr, S. B., Ames, B. N. Bacterial defenses against oxidative stress. Trends Genet. 6: 363-368; 1990.

[7] Madeo, F., Frohlich, E., Ligr, M., Grey, M., Sigrist, S. J., Wolf, D. H., Frohlich, K. U. Oxygen stress: a regulator of apoptosis in yeast. J. Cell Biol. 145: 757-767; 1999.

[8] Carmel-Harel, O., Storz, G. Roles of the glutathione- and thioredoxin-dependent reduction systems in the Escherichia coli and saccharomyces cerevisiae responses to oxidative stress. Annu. Rev. Microbiol. 54: 439-461; 2000.

[9] Collinson, L. P., Dawes, I. W. Inducibility of the response of yeast cells to peroxide stress. J. Gen. Microbiol. 138: 329-335; 1992.

[10] Jamieson, D. J. Saccharomyces cerevisiae has distinct adaptive responses to both hydrogen peroxide and menadione. J. Bacterial. 174: 6678-6681; 1992.

[11] Jamieson, D. J., Rivers, S. L., Stephen, D. W. Analysis of Saccharomyces cerevisiae proteins induced by peroxide and superoxide stress. Microbiology 140: 3277-3283; 1994.

[12] Longo, V. D., Ellerby, L. M., Bredesen, D. E., Valentine, J. S., Gralla, E. B. Human Bcl-2 reverses survival defects in yeast lacking superoxide dismutase and delays death of wild-type yeast. J. Cell Biol. 137: 1581-1588; 1997.

[13] Sturtz, L. A., Diekert, K., Jensen, L. T., Lill, R., Culotta, V. C. A fraction of yeast $\mathrm{Cu}, \mathrm{Zn}$-superoxide dismutase and its metallochaperone, CCS, localize to the intermembrane space of mitochondria. A physiological role for SOD1 in guarding against mitochondria1 oxidative damage. J. Biol. Chem. 276: 38084-38089; 2001.

[14] Jin, C., Reed, J. C. Yeast and apoptosis. Nat. Rev. Mol. Cell Biol. 3: 453-459; 2002.

[15] Frohlich, K.-U., Madeo, F. Apoptosis in yeast-a monocellular organism exhibits altruistic behavior. FEBS Lett. 473: 6-9; 2000.

[16] Hanada, M., Aime-Sempe, C., Sato, T., Reed, J. C. Structure-function analysis of $\mathrm{Bcl}-2$ protein. Identification of conserved domains important for homodimerization with Bcl-2 and heterodimerization with Bax. J. Biol. Chem 270: 11962-1 1969; 1995.

[17] Greenhalf, W., Stephan, C., Chaudhuri, B. Role of mitochondria and C-terminal membrane anchor of Bcl-2 in Bax induced growth arrest and mortality in Saccharomyces cerevisiae. FEBS Lett. 380: 169-175; 1996.

[18] Kang, J. J., Schaber, M. D., Srinivasula, S. M., Alnemri, E. S., Litwack, G., Hall, D. J., Bjornsti, M. A. Cascades of mammalian caspase activation in the yeast Saccharomyces cerevisiae. J. Biol. Chem. 274: 3189-3198; 1999.

[19] Nigro, J. M., Sikorski, R., Reed, S. I., Vogelstein, B. Human p53 and CDC2Hs genes combine to inhibit the proliferation of Saccharomyces cerevisiae. Mol. Cell. Biol. 12: 1357-1365; 1992.

[20] James, C., Gschmeissner, S., Fraser, A., Evan, G. I. CED4 induces chromatin condensation in Schizosaccharomyces pombe and is inhibited by direct physical association with CED-9. Curr. Biol. 7: 246-252; 1997.

[21] Tao, W., Kurschner, C., Morgan, J. I. Modulation of cell death in yeast by the Bcl-2 family of proteins. J. Biol. Chem. 272: 15547-15552; 1997.
[22] Jurgensmeier, J. M., Krajewski, S., Armstrong, R. C., Wilson, G. M., Oltersdorf, T., Fritz, L. C., Reed, J. C., Ottilie, S. Bax- and Bak-induced cell death in the fission yeast Schizosaccharomyces pombe. Mol. Biol. Cell 8: 325-339; 1997.

[23] Sato, T., Hanada, M., Bodrug, S., Irie, S., Iwama, N., Boise, L. H., Thompson, C. B., Golemis, E., Fong, L., Wang, H. G., Reed, J. C. Interactions among members of the Bcl-2 protein family analyzed with a yeast two-hybrid system. Proc. Natl. Acad. Sci. USA 91: 9238-9242; 1994.

[24] Madeo, F., Herker, E., Maldener, C., Wissing, S., Lachelt, S., Herlan, M., Fehr, M., Lauber, K., Sigrist, S. J., Wesselborg, S., Frohlich, K. U. A caspase-related protease regulates apoptosis in yeast. Mol. Cell 9: 911-917; 2002.

[25] Matsuyama, S., Nouraini, S., Reed, J. C. Yeast as a tool for apoptosis research. Curr. Opin. Microbiol. 2: 618-623; 1999.

[26] Laun, P., Pichova, A., Madeo, F., Fuchs, J., Ellinger, A., Kohlwein, S., Dawes, I., Frohlich, K. U., Breitenbach, M. Aged mother cells of Saccharomyces cerevisiae show markers of oxidative stress and apoptosis. Mol. Microbiol. 39: 1166$1173 ; 2001$.

[27] Kampranis, S., Damianova, R., Atallah, M., Toby, G., Kondi, G., Tsichlis, P. N., Makris, A. M. A novel plant glutathione $S$-transferase/peroxidase suppresses Bax lethality in yeast. J. Biol. Chem. 275: 29207-29216; 2000.

[28] Schiestl, R. H., Gietz, R. D. High efficiency transformation of intact yeast cells using single stranded nucleic acids as a carrier. Curr. Genet. 16: 339-346; 1989.

[29] Yang, E., Korsmeyer, S. J. Molecular thanatopsis: a discourse on the BCL2 family and cell death. Blood 88: 386$401 ; 1996$.

[30] Boise, L. H., Gonzalez-Garcia, M., Postema, C. E., Ding, L., Lindsten, T., Turka, L. A., Mao, X., Nunez, G., Thompson, C. B. bcl-x, a bcl-2-related gene that functions as a dominant regulator of apoptotic cell death. Cell 74: 597-608; 1993.

[31] Hengartner, M. O., Horvitz, H. R. The ins and outs of programmed cell death during C. elegans development. Philos. Trans. R. Soc. Lond. B Biol. Sci. 345: 243-246; 1994.

[32] Gyuris, J., Golemis, E., Chertkov, H., Brent, R. Cdil, a human G1 and $S$ phase protein phosphatase that associates with Cdk2. Cell 75: 791-803; 1993.

[33] Matsuyama, S., Schendel, S. L., Xie, Z., Reed, J. C. Cytoprotection by Bcl-2 requires the pore-forming $\alpha 5$ and $\alpha 6$ helices. J. Biol. Chem. 273: 30995-31001; 1998.

[34] Thaw, H. H., Lukinius, A., Brunk, U. T., Collins, V. P. An approach to the assessment of membrane stability of cultured cells. Eur. J. Cell Biol. 29: 236-243; 1983.

[35] Ross, D. D., Wooten, P. J., Sridhara, R., Ordonez, J. V., Lee, E. J., Schiffer, C. A. Enhancement of daunorubicin accumulation, retention, and cytotoxicity by verapamil or cyclosporin A in blast cells from patients with previously untreated acute myeloid leukemia. Blood 82: 1288-1299; 1993.

[36] Davidson, J. F., Whyte, B., Bissinger, P. H., Schiestl, R. H. Oxidative stress is involved in heat-induced cell death in Saccharomyces cerevisiae. Proc. Natl. Acad. Sci USA 93: 51165121; 1996.

[37] LeBel, C., Ischiropoulos, H., Bondy, S. C. Evaluation of the probe $2^{\prime}, 7^{\prime}$-dichlorofluorescin as an indicator of reactive 
oxygen species formation and oxidative stress. Chem Res. Toxicol. 5: 227-231; 1992.

[38] Gavrieli, Y., Sherman, Y., Ben-Sasson, S. A. Identification of programmed cell death in situ via specific labeling of nuclear DNA fragmentation. J. Cell Biol. 119: 493-501, 1992.

[39] Sakahira, H., Enari, M., Ohsawa, Y., Uchiyama, Y., Nagata, S. Apoptotic nuclear morphological change without DNA fragmentation. Curr. Biol. 9: 543-546; 1999.

[40] Ligr, M., Madeo, F., Frohlich, E., Hilt, W., Frohlich, K. U., Wolf, D. H. Mammalian Bax triggers apoptotic changes in yeast. FEBS Lett. 438: 61-65; 1998.

[41] Hockenbery, D. M., Oltvai, Z. N., Yin, X. M., Milliman, C. L., Korsmeyer, S. J. Bcl-2 functions in an antioxidant pathway to prevent apoptosis. Cell 75: 241-251; 1993.

[42] Kane, D. J., Sarafian, T. A., Anton, R., Hahn, H., Gralla, E. B., Valentine, J. S., Ord, T., Bredesen, D. E. Bcl-2 inhibition of neural death: decreased generation of reactive oxygen species. Science 262: 1274-1277; 1993.

[43] Tyurina, Y. Y., Tyurin, V. A., Carta, G., Quinn, P. J., Schor, N. F., Kagan, V. E. Direct evidence for antioxidant effect of Bcl-2 in PC12 rat pheochromocytoma cells. Arch. Biochem. Biophys. 344: 413-423; 1997.

[44] Samali, A., Holmberg, C. I., Sistonen, L., Orrenius, S. Thermotolerance and cell death are distinct cellular responses to stress: dependence on heat shock proteins. FEBS Lett. 461: 306-310; 1999.

[45] Polla, B. S., Kantengwa, S., Francois, D., Salvioli, S., Franceschi, C., Marsac, C., Cossarizza, A. Mitochondria are selective targets for the protective effects of heat shock against oxidative injury. Proc. Natl. Acad. Sci. USA 93: 64586463; 1996.

[46] Sanchez, Y., Lindquist, S. L. HSP104 required for induced thermotolerance. Science 248: 11 12-1 115, 1990.
[47] Ameisen, J. C. On the origin, evolution, and nature of programmed cell death: a timeline of four billion years. Cell Death Differ. 9: 367-393, 2002.

[48] Madeo, F., Frohlich, E., Frohlich, K. U. A yeast mutant showing diagnostic markers of early and late apoptosis. J. Cell Biol. 139: 729-734, 1997.

[49] Lowary, P. T., Widom, J. Higher-order structure of Saccharomyces cerevisiae chromatin. Proc. Natl. Acad. Sci. USA 86: 8266-8270, 1989.

[50] Zhang, H., Reed, J. C. Studies of apoptosis proteins in yeast. Methods Cell Biol. 66: 453-468; 2001.

[51] Levine, A., Belenghi, B., Damari-Weisler, H., Granot, D. Vesicle-associated membrane protein of Arabidopsis suppresses Bax-induced apoptosis in yeast downstream of oxidative burst. J. Biol. Chem. 276: 46284-46289; 2001.

[52] Moon, H., Baek, D., Lee, B., Prasad, D. T., Lee, S. Y., Cho, M. J., Lim, C. O., Choi, M. S., Bahk, J., Kim, M. O., Hong, J. C., Yun, D. J. Soybean ascorbate peroxidase suppresses Bax-induced apoptosis in yeast by inhibiting oxygen radical generation. Biochem. Biophys. Res. Commun. 290: 457-462; 2002.

[53] Pan, L., Kawai, M., Yu, L. H., Kim, K. M., Hirata, A., Umeda, M., Uchimiya, H. The Arabidopsis thaliana ethylene-responsive element binding protein (AtEBP) can function as a dominant suppressor of Bax-induced cell death of yeast. FEBS Lett. 508: 375-378; 2001.

[54] Dickman, M. B., Park, Y. K., Oltersdorf, T., Li, W., Clemente, T., French, R. Abrogation of disease development in plants expressing animal antiapoptotic genes. Proc. Natl. Acad. Sci. USA 98: 6957-6962; 2001.

[55] Grant, J. J., Loake, G. J. Role of reactive oxygen intermediates and cognate redox signaling in disease resistance. Plant Physiol. 124: 21-29; 2000.

\section{Abbreviations}

\begin{tabular}{ll}
\hline CFU & colony forming units \\
DAPI & diaminophenylindole \\
DCFH-DA & 5,6, carboxy-2', $7^{\prime}$-dichlorofluorescin-diacetate \\
DCF-2', $7^{\prime}$ & dichlorofluorescein \\
FITC & fluoroscene isothiocyanate \\
$\mathrm{H}_{2} \mathrm{O}_{2}$ & hydrogen peroxide \\
$\mathrm{Hsp}^{\bullet}$ & heat-shock protein \\
$\mathrm{O}_{2}$ & superoxide anion \\
$\mathrm{OH}$ & hydroxyl radical \\
$\mathrm{PBS}^{*}$ & phosphate-buffered saline \\
ROS & reactive oxygen species \\
SD & synthetic dropout \\
TUNEL & terminal deoxynucleotidyl transferase-mediated dUTP nick end labeling
\end{tabular}

